\title{
Fear of COVID-19 as a buffer in the relationship between perceived stress and life satisfaction in the Polish population at the beginning of the global pandemic
}

\begin{abstract}
BACKGROUND
COVID-19 is a significant threat to human life and health. It makes people experience fear, stress, anxiety and mood disorders, which have a negative impact on their psychological well-being. The aim of the study was to determine the relationship between fear of COVID-19, perceived stress, and life satisfaction during the coronavirus pandemic.
\end{abstract}

\section{PARTICIPANTS AND PROCEDURE}

907 Polish people (522 women and 385 men) participated in this study. The Perceived Stress Scale (PSS-10), the Fear of COVID-19 Scale (FOC-6) and the Satisfaction with Life Scale (SWLS) were used in the study.

\section{RESULTS}

Fear of COVID-19 and perceived stress were positively correlated with each other and both negatively related to life satisfaction. Moderation analysis showed that fear of COVID-19 acted as a buffer between perceived stress and life satisfaction - people with a high level of fear of
COVID-19 and perceived stress had greater life satisfaction than those with high levels of stress but low levels of fear of COVID-19.

\section{CONCLUSIONS}

During the COVID-19 pandemic, people experience significant stress and fear of infection, which negatively affect their life satisfaction. It can be assumed that during a global pandemic, most stressors are not directly linked to the risk of infection. Loss of job, isolation, lack of social support, or a total change in lifestyle may be more threatening to the well-being than the risk of infection, which many people do not consider as dangerous. Therefore, it can be assumed that people who experience a strong fear of COVID-19 may perceive inconveniences resulting from restrictions as less oppressive than people who do not feel fear.

\section{KEY WORDS}

stress; life satisfaction; moderation; COVID-19; fear of coronavirus 


\section{BACKGROUND}

COVID-19, caused by the novel coronavirus SARS$\mathrm{CoV}-2$, occurred in Wuhan, Hubei Province, China since December 2019, causing an outbreak of acute infectious pneumonia. The disease has spread subsequently to the rest of the world, causing an ongoing pandemic, which was announced by the World Health Organisation (WHO) on March 11. The clinical course of the disease varies from mild or even asymptomatic to severe respiratory failure and death (Gabutti et al., 2020). The proportion of critically ill patients was 23.4\%. According to the WHO, COVID-19 mortality is around $5.5 \%$ (WHO, 2020). The prognosis is worse in elderly patients with comorbidities such as diabetes, cardiovascular disease and cancer (Di Gennaro et al., 2020; Ye et al., 2020). According to the WHO, on June 14 there were 7,690,708 cases in the world, including 283,153 deaths; the largest number of cases was in Europe - 1,755,790 including 427,630 deaths (WHO, 2020). The first case of COVID-19 in Poland was found on March 4, and by June 15, 29,788 cases of SARS-CoV-2 infection had been confirmed, and 1256 people had died. On March 20, epidemic status was announced. All schools and universities were closed, leaving the house was forbidden, with the exception of satisfying the most important life needs, and there were high penalties for breaking the quarantine rules.

In addition to physical and health problems, COVID-19 also has a serious impact on the mental functioning of the society. Even if most people do not get infected, they are exposed to the psychological consequences of a pandemic (Xiao et al., 2020). COVID-19 is a significant source of stress due to rapid spread, strong infectivity, mortality in severe cases, and lack of medicine and vaccine (Fardin, 2020; Gao et al., 2020; Ornell et al., 2020). During the pandemic, people are likely to feel emotional distress due to uncertainty about the future, fear of getting infected, news about new confirmed cases and the increased death toll (Zhang et al., 2020). The COVID-19 outbreak caused drastic changes in everyday life and dramatically changed people's lifestyles because of the social distancing practice, stay-at-home orders, and being disconnected from others with whom they usually interact. Because of the closure of workplaces and schools, people started working and studying from home and had to adapt to remote work and new technologies (Chen et al., 2020; Xiao et al., 2020). Perceived level of stress can be even stronger for those who have to deal with unemployment, grief, chronic diseases and health issues, and for people who need to manage family problems while working at home (Zhang et al., 2020).

Outbreaks of serious contagious diseases contribute to fear and anxiety among the population, which was also confirmed during previous epidemics (Su et al., 2007). During previous global pandemics, clear links between pandemic fear and increased symptoms of stress, post-traumatic stress disorder, anxiety and health anxiety, panic attacks and suicide have been demonstrated (Chong et al., 2004; Hawryluck et al., 2004; Jeong et al., 2016; Wheaton et al., 2012; Wu et al., 2009; Yip et al., 2010).

People are likely to feel helpless and experience fear of contracting the virus and dying. They may also be afraid of being stigmatized because of getting infected or staying in quarantine (Hall et al., 2008). Characteristic emotional responses of Chinese society to the outbreak of the SARS epidemic, which took place 17 years ago, include serious fears, anxiety and increased emotional tension (Chiu et al., 2003; Zhu et al., 2008). During the outbreak of the swine flu epidemic, around $10-30 \%$ of the general population was very or moderately concerned about the possibility of contracting the virus (Rubin et al., 2010), and due to the closure of schools and workplaces, negative emotions felt by individuals were compounded (Van Bortel et al., 2016). Increased fear has been associated with engaging in hygienic behaviours such as hand disinfection, and avoiding public transport and crowds (Wheaton et al., 2012). In addition, pandemic diseases such as H1N1 influenza or current COVID-19 are widely talked about in mass media, which may result in high levels of fear and compensatory behaviour (Fardin, 2020; Wheaton et al., 2012).

Therefore, it is thought that the consequences of the COVID-19 pandemic will also be associated with stress, anxiety and fear, which may lead to many psychological problems that can influence people's quality of life (Zhang et al., 2020). However, we still know little about the influence of the COVID-19 pandemic on people's life satisfaction, and what factors intensify or buffer this effect. Many previous studies have shown that stress negatively influences people's well-being and life satisfaction. People experience emotional exhaustion, negative emotions and less vitality in stressful situations (Bliese et al., 2017; Mc Gee et al., 2018). However, so far little research has been published about the impact of the COVID-19 pandemic on people's quality of life. In an American study, it was found that the pandemic severity relates to people's well-being and that COVID-19 makes people experience more negative emotions. Because of COVID-19 people are more likely to feel anxious, scared, angry and sad (Zhang et al., 2020). During a pandemic, fear can increase levels of anxiety and stress. A Turkish study found that fear of COVID-19 is positively related to stress and anxiety and negatively with life satisfaction. In addition, in this study it was found that fear of COVID-19 increases the level of anxiety and stress, and decreases life satisfaction (Satici et al., 2020). Several other studies have shown that fear of COVID-19 increases levels of psychological distress and has a negative 
impact on people's mental health. Chinese studies show that more than $25 \%$ of their society feels at least moderate levels of stress or anxiety during the coronavirus pandemic (Qiu et al., 2020; Wang et al., 2020). Ahorsu et al. (2020) stated that fear of COVID-19 is positively associated with negative emotions and that concerns about the risk of infection increase anxiety and stress. Constant information about many fatalities around the world and the growing number of cases lead to the increasing fear of COVID-19.

However, during the pandemic, stress is not just about the fear of getting infected. People feel stress because of isolation, lifestyle changes, job loss and lack of social contact. In a study on the Polish population, it was shown that the fear of COVID-19, although negatively correlated with a sense of coherence, may weaken the effect of stress on the level of this resource. It was observed that people with high levels of fear of COVID-19 and stress had higher sense of coherence than those with a high level of stress but a low level of fear of COVID-19. It is possible that surveyed people with strong fear of COVID-19 felt that all restrictions and stay-at-home orders made sense and their purpose was to protect against the contagion (Dymecka et al., 2020). During the previous SARS epidemic, it was shown that this disease affects all aspects of people's quality of life (Kwek et al., 2006). But we still know little about the influence of stress during the COVID-19 pandemic on people's life satisfaction, and whether fear of COVID-19 worsens or buffers this effect.

Therefore, the purpose of the current research was to determine the relationship between fear of COVID, stress and life satisfaction of Polish society. We hypothesize that: (1) stress will be significantly and negatively associated with life satisfaction; (2) fear of COVID-19 will be significantly and negatively associated with life satisfaction; (3) stress and fear of COVID-19 will be significantly and positively related to each other. Since the Polish results show that fear of COVID-19 acted as a buffer in the relationship between stress and sense of coherence (Dymecka et al., 2020), we would also like to verify whether fear of COVID-19 will act as a moderator in the relationship between stress and life satisfaction.

\section{PARTICIPANTS AND PROCEDURE}

\section{PARTICIPANTS}

Due to the epidemiological threat, study participants were recruited via social media websites. They were informed about the anonymity of the study and that they could stop filling in the survey at any time and without giving any reason. All respondents gave their informed consent to participate in this study. In
Table 1

Characteristics of the studied sample $(N=907)$

\begin{tabular}{|c|c|c|}
\hline & $M(S D)$ & Min-Max \\
\hline Age (all participants) & $\begin{array}{c}39.28 \\
(15.30)\end{array}$ & $18.00-102.00$ \\
\hline Age (women) & $\begin{array}{c}38.59 \\
(15.22)\end{array}$ & $18.00-101.00$ \\
\hline \multirow[t]{2}{*}{ Age (men) } & $\begin{array}{c}40.21 \\
(15.38) \\
\end{array}$ & $18.00-102.00$ \\
\hline & $n$ & Percentage \\
\hline \multicolumn{3}{|l|}{ Gender } \\
\hline Women & 522 & 57.55 \\
\hline Men & 385 & 42.45 \\
\hline \multicolumn{3}{|l|}{ Education } \\
\hline Elementary school & 28 & 3.09 \\
\hline Vocational & 65 & 7.17 \\
\hline High school & 347 & 38.26 \\
\hline University & 467 & 51.49 \\
\hline \multicolumn{3}{|l|}{ Place of residence } \\
\hline Village & 220 & 24.26 \\
\hline Town & 410 & 45.20 \\
\hline City & 277 & 30.54 \\
\hline \multicolumn{3}{|l|}{ Professional activity } \\
\hline Unemployed & 268 & 29.55 \\
\hline Employed & 639 & 70.45 \\
\hline
\end{tabular}

the end, 907 people living in Poland between the age of 18 and 102 participated in this study. All people under 18 years of age were excluded from the analysis. Digitally excluded older adults could complete the survey by phone. The exact data are shown in Table 1 . The presented study was in accordance with the guidelines of the Bioethics Committee of the University of Opole.

\section{MEASURES}

Three questionnaires were used in this study.

Perceived Stress Scale. The perceived level of stress was measured with the Perceived Stress Scale (PSS-10; Cohen et al., 1983). It is a 10-item questionnaire with 4-point answer scale from 0 (never) to 4 (very often). It showed good psychometric properties in the current study (Cronbach's $\alpha=.86$, McDonald's total $\omega=.86)$.
COVID-19, stress, pandemic, quality of life 
Joanna Dymecka, Rafał Gerymski, Anna MachnikCzerwik
Fear of COVID-19 Scale. Fear of the coronavirus was measured with the authors' Fear of COVID-19 Scale (FOC-6; Dymecka et al., 2020) - a 6-item questionnaire with a 1-5 answer scale. It presented good psychometric properties (Cronbach's $\alpha=.83$, McDonald's total $\omega=.84, \mathrm{CFI}=.957, \mathrm{TLI}=.928, \mathrm{RMSEA}=.111$ [LLCI $=.093$, ULCI $=.130]$ - note: no covariances were set between items). Scale items can be found in the Appendix (see Appendix 1 for items in English and Appendix 2 for items in Polish).

Satisfaction with Life Scale. The Satisfaction with Life Scale (SWLS; Diener et al., 1985) was also used. It is a 5-item questionnaire with a 7-point answer scale from 1 (definitely disagree) to 7 (completely agree). It had good reliability in the current study (Cronbach's $\alpha=.87$, McDonald's total $\omega=.88$ ).

\section{STATISTICAL ANALYSIS}

Statistical analyses were performed with SPSS Statistics version 24. Pearson's $r$ correlation was used to identify the relationships between tested variables. The moderation analysis was performed with the PROCESS 3.4 macro (Hayes, 2017). Power analysis was performed using $G^{*}$ Power 3.1.9.7 (Faul, Erdfelder, Buchner, \& Lang, 2020). An $\alpha$ level of .05 was used in all presented analyses.

\section{RESULTS}

\section{RELATIONSHIP BETWEEN STRESS, FEAR OF CORONAVIRUS AND LIFE SATISFACTION}

In the first step of the statistical analysis, it was decided to evaluate whether stress, fear of COVID-19 and life satisfaction are significantly related. Pearson's $r$ correlation showed a statistically significant and positive, moderate relationship between stress and fear of COVID-19. Stress was also moderately negatively associated with life satisfaction. There was also a statistically significant, weak and negative relationship between fear of COVID-19 and life satisfaction. Detailed data are shown in Table 2.

\section{MODERATION ANALYSIS}

In order to verify the proposed moderation model, analysis using the PROCESS macro version 3.4 was used (Hayes, 2017). The bootstrapping method was used with the declared number of 5000 samples (Preacher \& Hayes, 2008). The PROCESS macro allows standardized coefficients to be obtained only for mediation models. Therefore, before performing the analysis, variables were z-scored in order to obtain $\beta$ coefficients. Model 1 analysis was used to verify

\section{Table 2}

Results of the Pearson's r correlation analysis $(N=907)$

\begin{tabular}{lccccc}
\hline & $M$ & $S D$ & 1 & 2 & 3 \\
\hline 1. Stress & 20.57 & 5.87 & - & & \\
2. Fear of COVID-19 & 21.41 & 5.84 & $.34^{* * *}$ & - & $-.10^{* *}$ \\
3. Life satisfaction & 22.67 & 5.99 & $-.40^{* *}$ & - & - \\
\hline Note. ${ }^{* *} p<.01,{ }^{* * *} p<.001$. & & & &
\end{tabular}

Table 3

Results of the moderation analysis using PROCESS 3.4 Model $1(N=907)$

\begin{tabular}{|c|c|c|c|c|c|c|c|c|}
\hline Path & & & $\beta$ & $S E$ & $t$ & $p$ & LLCI & ULCI \\
\hline $\mathrm{X}$ & $\rightarrow$ & $\mathrm{Y}$ & -.41 & .03 & -12.36 & $<.001$ & -.465 & -.338 \\
\hline W & $\rightarrow$ & $\mathrm{Y}$ & .04 & .03 & 1.26 & .207 & -.023 & .105 \\
\hline$X^{*} W$ & $\rightarrow$ & $\mathrm{Y}$ & .08 & .03 & 2.66 & .008 & .020 & .134 \\
\hline \multirow[t]{4}{*}{ Conditional effects } & & & $\beta$ & $S E$ & $t$ & $p$ & LLCI & ULCI \\
\hline & & $-1 \mathrm{SD}$ & -.48 & .04 & -11.50 & $<.001$ & -.560 & -.397 \\
\hline & & M & -.40 & .03 & -12.36 & $<.001$ & -.465 & -.338 \\
\hline & & $+1 \mathrm{SD}$ & -.32 & .04 & -7.16 & $<.001$ & -.414 & -.236 \\
\hline
\end{tabular}

Note. X - stress, W - fear of COVID-19, Y - life satisfaction. 
the moderation model. The results of the analysis are presented in Table 3.

Fear of COVID-19 was not a direct predictor of life satisfaction. Model 1 analysis showed that fear of COVID-19 was the moderator in the relationship between stress and life satisfaction. Analysis of obtained $\beta$ coefficients suggests that fear of COVID-19 was a buffer in the relationship between stress and life satisfaction - it weakened the impact of stress on the hedonistic dimension of well-being. A visual representation of the moderated effect is presented in Figure 1.

\section{POWER ANALYSIS}

Post-hoc power analysis using $\mathrm{G}^{*}$ Power 3.1.9.7 (Faul et al., 2020) showed that for a small effect size $\left(f^{2}=.02\right)$ and the significance of $\alpha=.05$, the obtained sample was sufficient to obtain power of .98 .

\section{DISCUSSION}

The aim of the study was to determine the relationship between fear of COVID-19, perceived stress and life satisfaction during the coronavirus pandemic. The analyses show that the relationship between all tested variables was significant. Fear of COVID-19 and perceived stress were positively correlated with each other and both negatively related to life satisfaction. Moderation analysis showed that fear of COVID-19 acted as a buffer between perceived stress and life satisfaction - people with a high level of fear of COVID-19 and perceived stress had greater life satisfaction than those with high levels of stress but low levels of fear of COVID-19.

The outbreak of COVID-19 has been dominating the global media for several months. It should not be surprising since the virus is new, spreads quickly and its death rate exceeds $5.5 \%$. There are many uncertainties regarding its origin and course. The number of COVID-19 infections is constantly increasing, as are the number of deaths and cases of people under quarantine around the world (Asmundson \& Taylor, 2020). Due to its rapid spread and high mortality rate, people are likely to feel the fear COVID-19. The feature of any contagious disease is fear. It might be related to fear of infection, death and loss of family members, as well as meeting people who may be infected (Fardin, 2020). Fear is related to the speed at which the virus spreads and to the fact that it is invisible. High levels of morbidity and mortality also affect fear levels (Ahorsu et al., 2020). During the current pandemic, people are also afraid of serious health complications associated with COVID-19, forced hospitalization and long quarantine. Another reason for fear is the possibility of passing on the infection to loved ones who might not survive the dis-

\section{Figure 1}

\section{Results of the moderation analysis - simple plots}

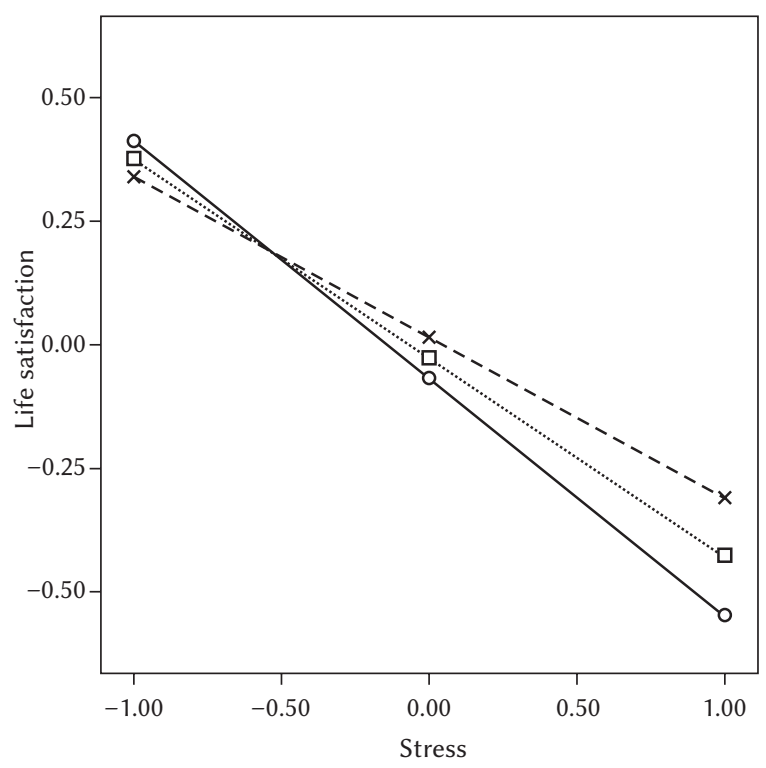

COVID-19, stress, pandemic, quality of life

ease. The cause of fear is also the uncertainty about how the epidemic will develop, which causes fear of the unknown. The fear of coronavirus is probably due to its novelty and uncertainty of how dangerous the current epidemic can become and is much greater than the fear of seasonal flu (Asmundson \& Taylor, 2020). Because of that, it is not surprising that both during COVID-19 and previous epidemics, studies have shown a high level of fear, stress and anxiety among various groups of people.

Fear can be initially caused by a significant shortage of medical masks and disinfectants. It has been estimated that even more than $30 \%$ of the population can show a significant increase in anxiety. Also one fifth of people may develop depression symptoms and sleep problems (Huang \& Zhao, 2020). The uncertainty associated with the spread of the epidemic and its progression increases the psychological pressure felt by society. The reason for this is the fear of infection and the fact that the epidemic is difficult to control (Huang \& Zhao, 2020). In another Chinese study conducted at the beginning of the epidemic, the psychological impact of the spread of the virus on the occurrence of depression, stress and anxiety in the population was assessed. Approximately half of the respondents classified the psychological impact of the epidemic as moderate to severe, and about a third reported moderate to severe anxiety. These people spent most of their time at home, had 
Joanna Dymecka, Rafał Gerymski, Anna MachnikCzerwik no contact with infected people, and had no physical symptoms (Wang et al., 2020).

The current study also showed that the subjects felt significant levels of perceived stress. The current study's mean result in the PSS-10 questionnaire (20.57), as well as mean results obtained by other researchers (17.4; Gamonal-Limcaoco et al., 2020) using the same questionnaire during this epidemic are higher than the population average (< 13 according to Cohen \& Williamson, 1988; 16.6 for the Polish population according to Juczyński, 2001) and similar to those recorded in previous epidemics (18.5; Chua et al., 2004). Researchers conclude that a pandemic increases stress levels, as it has already been shown in many studies, stress negatively influences people's well-being (Bliese et al., 2017; Zhang et al., 2020). Further studies have also confirmed that over 35\% of respondents felt distressed, because the epidemic caused changes in many aspects of human life and forced many people to isolate (Qiu et al., 2020). Similar observations were noted in Japan, where attention was also paid to the negative economic impact of the pandemic (Shigemura et al., 2020).

COVID-19 is a global threat to public health, which requires drastic control measures, such as quarantine, isolation, social distancing, and remote work. It disrupted every aspect of everyday life, caused economic difficulties and made people feel helpless and hopeless, due to the threat of contracting a potentially deadly disease (Brooks et al., 2020). Previous epidemics have not had such a significant impact on the lives of people in so many societies. The COVID-19 pandemic is inseparably connected with a sense of helplessness, loss of the sense of security, protection, financial stability and the ability to predict a better future (Polizzi et al., 2020). In addition, during the current pandemic, some of the main causes of stress are uncertainty associated with the disease, fear of infection, death and loss of loved ones, depression after the loss of friends and family members, isolation and the need to be in quarantine, the inability to go to work and school, a lot of false information in social media and the economic crisis (Fardin, 2020; Sood, 2020).

In the current study, both stress and fear of COVID-19 were negatively associated with life satisfaction. However, the fear of coronavirus acted as a buffer between stress and life satisfaction. Our results are inconsistent with the results of previous studies, which show that fear of COVID-19 increases stress levels, and thus reduces life satisfaction (Satici et al., 2020). The presented simple plots show that in the situation of high stress, life satisfaction is higher for people with high fear of COVID-19. This result may seem surprising, but the fear of COVID-19, although it is negatively correlated with life satisfaction, may weaken the effect of stress on the level of how people evaluate their lives and how satisfied they are with it. In our previous study, it was indicated that fear of COVID-19 was also a buffer between perceived stress and the level of sense of coherence (Dymecka et al., 2020).

During the COVID-19 pandemic, the virus is a major stressor for everyone. However, there are other stressors that emerge with the pandemic that further worsen the situation (Zhang et al., 2020). COVID-19 had an impact on most aspects of human life, which are inextricably linked to its quality and satisfaction. The pandemic resulted in family deorganization, closure of school, workplaces and public places, changes in work procedures and isolation. Moreover, it may bring uncertainty for the economic and social consequences of this great tragedy (Ornell et al., 2020). Many people have experienced a worsening of their financial situation due to the pandemic. Some people lost their jobs or worked part-time. This situation was reported by over a quarter of our respondents. Those who worked from home may also experience stress. They need to adjust to a new work style, and learn to work through new technologies (e.g., Zoom, MS Teams). Family conflicts might have been another problem, as they could arise when people have to spend a prolonged amount of time together in a small space. Working parents had to reconcile work and childcare. Work-family conflict also serves as an extra stressor for them (Zhang et al., 2020).

Another important stressor, affecting the quality of life, was isolation and the inability to meet with loved ones, even during Easter, which many people had to spend alone. During COVID-19 people were more isolated than ever before. Meetings with family and friends help people feel emotionally connected and gain social support that helps in coping with stress and is associated with greater life satisfaction (Ashida \& Heaney, 2008; Cobb, 1976; Dymecka \& Gerymski, 2019).

Isolation and stay-at-home orders have rendered free time activities impossible. When people cannot get rest, they are more likely to feel distressed and emotionally exhausted. Moreover, after people stay at home for a long time, they are likely to generate negative emotions (Zhang et al., 2020). The inability to move freely was another stressor. During the obligatory isolation, there were several long weekends that Poles used to spend in tourist destinations. Therefore, it can be assumed that for many people, stay-at-home orders, physical inactivity and the inability to travel freely were more stressful than the possibility of infection. The fact that religious activities were forbidden during the COVID-19 pandemic might be a major source of stress for some people, as faith is an important psychological resource for them (Koenig et al., 1998).

Accordingly, it can be assumed that during a global pandemic, most stressors are not directly linked to the risk of infection. Loss of job and income, isola- 
tion, no contact with friends, and thus lack of social support, or a total change in lifestyle in connection with work from home and simultaneous childcare may be more threatening to the well-being than the risk of infection, which many people do not consider as dangerous. Therefore, it can be assumed that people who experience a strong fear of COVID-19 may perceive inconveniences resulting from restrictions as less oppressive than people who do not feel fear. If we feel a strong fear about our own health and life, then the possibility of losing goods such as part of income, the possibility of traveling, meeting friends or outdoor activities is a small sacrifice compared to protecting health and life. Therefore, it can be assumed that those who feel fear of COVID-19 consider the restrictions as more meaningful and with important purpose, and therefore may be less likely to oppose them. They may also feel fewer negative emotions, such as sadness and anger, which have a negative impact on well-being and life satisfaction.

In summary, during the COVID-19 pandemic, people experience significant stress and fear of infection, which negatively affect their life satisfaction. The current study has shown that fear of COVID-19 can act as a buffer against the negative effects of stress on life satisfaction and well-being. Even though it provides new and relevant data, it is not free of limitations. The presented results are based only on the Polish population. International research should be carried out in order to verify the significance of the proposed model. This would additionally require the use of cultural equivalence analysis in order to compare various cultural groups. The method of collecting data may also be a limitation of this study. All data were collected via the Internet, as personal contact with the subjects was impossible during the pandemic. Moreover, the tested moderated model may suggest causal relationships. In order to verify such relationships, a longitudinal study should be carried out.

\section{REFERENCES}

Ahorsu, D. K., Lin, C. Y., Imani, V., Saffari, M., Griffiths, M. D., \& Pakpour, A. H. (2020) The Fear of COVID19 Scale: Development and initial validation. International Journal of Mental Health and Addiction. https://doi.org/10.1007/s11469-020-00270-8

Ashida, S., \& Heaney, C. (2008). Differential associations of social support and social connectedness with structural features of social networks and the health status of older adults. Journal of Aging and Health, 20, 872-893. https:// doi.org/10.1177/0898264308324626

Asmundson, G. J. G., \& Taylor, S. (2020). Coronaphobia: Fear and the 2019-nCoV outbreak. Journal of Anxiety Disorders, 70, 102196. https:// doi.org/10.1016/j.janxdis.2020.102196
Bliese, P. D., Edwards, J. R., \& Sonnentag, S. (2017). Stress and well-being at work: a century of empirical trends reflecting theoretical and societal influences. Journal of Applied Psychology, 102, 389-402. https://doi.org/10.1037/apl0000109

Brooks, S. K., Webster, R. K., Smith, L. E., Woodland, L., Wessely, S., Greenberg, N., \& Rubin, G. J. (2020). The psychological impact of quarantine and how to reduce it: Rapid review of the evidence. Lancet, 395, 912-920. https://doi.org/10.1016/S01406736(20)30460-8

Chen, Q., Liang, M., Li, Y., Guo, J., Fei, D., Wang, L., He, L., Sheng, C., Cai, Y., Li, X., Wang, J., \& Zhang, Z. (2020). Mental health care for medical staff in China during the COVID-19 outbreak. Lancet Psychiatry, 7, e15-e16. https:// doi.org/10.1016/S2215-0366(20)30078-X

Chiu, H. F. K., Lam, L. C. W., \& Chiu, E. (2003). SARS and psychogeriatric - perspective and lessons from Hong Kong. International Journal of Geriatric Psychiatry, 18, 871-873. https://doi.org/10.1002/ gps. 1003

Chong, M., Wang, W., Hsieh, W., Lee, C., Chiu, N., Yeh, W., Huang, T., Wen, J., \& Chen, C. (2004). Psychological impact of severe acute respiratory syndrome on health workers in a tertiary hospital. British Journal of Psychiatry, 185, 127-133. https:// doi.org/10.1192/bjp.185.2.127

Chua, S. E., Cheung, V., Cheung, C., McAlonan, G. M., Wong, J. W., Cheung, E. P., Chan, M. T., Wong, M. M., Tang, S. W., Choy, K. M., Wong, M. K., Chu, C. M., \& Tsang, K. W. (2004). Psychological effects of the SARS outbreak in Hong Kong on high-risk health care workers. Canadian Journal of Psychiatry, 49, 391393. https://doi.org/10.1177/070674370404900609

Cobb, S. (1976). Social support as a moderator of life stress. Psychosomatic Medicine, 38, 300-314. https:// doi.org/10.1097/00006842-197609000-00003

Cohen, S., Kamarck, T., \& Mermelstein, R. (1983). A global measure of perceived stress. Journal of Health and Social Behavior, 24, 385-396. https:// doi.org/10.2307/2136404

Cohen, S., \& Williamson, G. (1988). Perceived stress in a probability sample of the United States. In: S. Spacapam \& S. Oskamp (Eds.), The social psychology of health (pp. 31-67). Sage.

Di Gennaro, F., Pizzol, D., Marotta, C., Antunes, M., Racalbuto, V., Veronese, N., \& Smith, L. (2020). Coronavirus diseases (COVID-19) current status and future perspectives: a narrative review. International Journal of Environmental Research and Public Health, 17, 2690. https://doi.org/10.3390/ijerph17082690

Diener, E. D., Emmons, R. A., Larsen, R. J., \& Griffin, S. (1985). The Satisfaction with Life Scale. Journal of Personality Assessment, 49, 71-75. https:// doi.org/10.1207/s15327752jpa4901_13

Dymecka, J., \& Gerymski, R. (2019). Niepełnosprawność a jakość życia pacjentów ze stwardnieniem
COVID-19, stress, pandemic, quality of life 
Joanna Dymecka, Rafał Gerymski, Anna MachnikCzerwik rozsianym. Mediacyjna rola zapotrzebowania na wsparcie społeczne [Disability and the quality of life of patients with multiple sclerosis. A mediating role of the need for social support]. Człowiek - Niepetnosprawność - Społeczeństwo, 46, 63-78. https://doi.org/10.5604/01.3001.0013.7573

Dymecka, J., Gerymski, R., \& Machnik-Czerwik, A. (2020). How does stress affect our life satisfaction during COVID-19 pandemic? Moderating mediation analysis of sense of coherence and fear of coronavirus. PsyArXiv. https://doi.org/10.31234/osf.io/3zjrx

Fardin, M. A. (2020). COVID-19 and anxiety: a review of psychological impacts of infectious disease outbreaks. Archives of Clinical Infectious Diseases. https://doi.org/10.5812/archcid.102779

Faul, F., Erdfelder, E., Buchner, A., \& Lang, A. G. (2020). G*Power Version 3.1.9.7 [Computer software]. Retrieved from http://www.psychologie. hhu.de/arbeitsgruppen/allgemeine-psychologieund-arbeitspsychologie/gpower.html

Gabutti, G., d'Anchera, E., Sandri, F., Savio, M., \& Stefanati, A. (2020). Coronavirus: Update related to the current outbreak of COVID-19. Infectious Diseases and Therapy, 9, 1-13. https://doi.org/10.1007/ s40121-020-00295-5

Gamonal-Limcaoco, S., Montero Mateos, E., Fernandez, J., \& Roncero, C. (2020). Anxiety, worry and perceived stress in the world due to the COVID-19 pandemic, March 2020. Preliminary results. MedRxiv. https://doi.org/10.1101/2020.04.03.20043992

Gao, J., Zheng, P., Jia, Y., Chen, H., Mao, Y., Chen, S., Wang, Y., Fu, H., \& Dai, J. (2020). Mental health problems and social media exposure during COVID-19 outbreak. PloS One, 15, e0231924. https://doi.org/10.1371/journal.pone.0231924

Hall, R. C., Hall, R. C., \& Chapman, M. J. (2008). The 1995 Kikwit Ebola outbreak: Lessons hospitals and physicians can apply to future viral epidemics. General Hospital Psychiatry, 30, 446-452. https://doi.org/10.1016/j.genhosppsych.2008.05.003

Hayes, A. F. (2017). Introduction to mediation, moderation, and conditional process analysis: a regression-based approach. Guilford Publications.

Hawryluck, L., Gold, W. L., Robinson, S., Pogorski, S., Galea, S., \& Styra, R. (2004). SARS control and psychological effects of quarantine, Toronto, Canada. Emerging Infectious Diseases, 10, 1206-1212. https:// doi.org/10.3201/eid1007.030703

Huang,Y., \& Zhao, N. (2020). Generalized anxiety disorder, depressive symptoms and sleep quality during COVID-19 outbreak in China: a web-based crosssectional survey. Psychiatry Research, 288, 112954. https://doi.org/10.1016/j.psychres.2020.112954

Jeong, H., Yim, H. W., Song, Y. J., Ki, M., Min, J. A., Cho, J., \& Chae, J. H. (2016). Mental health status of people isolated due to Middle East respiratory syndrome. Epidemiology and Health, 38, e2016048. https://doi.org/10.4178/epih.e2016048
Juczyński, Z. (2001). Narzędzia pomiaru w promocji i psychologii zdrowia [Measurement tools in promotion and health psychology]. Pracownia Testów Psychologicznych Polskiego Towarzystwa Psychologicznego.

Koenig, H., George, L., \& Peterson, B. (1998). Religiosity and remission of depression in medically ill older patients. The American Journal of Psychiatry, 155, 536-342. https://doi.org/10.1176/ajp. 155.4.536

Kwek, S. K., Chew, W. M., Ong, K. C., Ng, A.W., Lee, L. S., Kaw, G., \& Leow, M. K. (2006). Quality of life and psychological status in survivors of severe acute respiratory syndrome at 3 months post discharge. Journal of Psychosomatic Research, 60, 513-519. https://doi.org/10.1016/j.jpsychores.2005.08.020

Mc Gee, S. L., Höltge, J., Maercker, A., \& Thoma, M. V. (2018). Sense of coherence and stress-related resilience: Investigating the mediating and moderating mechanisms in the development of resilience following stress or adversity. Frontiers in Psychiatry, 9, 378. https://doi.org/10.3389/fpsyt.2018.00378

Ornell, F., Schuch, J. B., Sordi, A. O., \& Kessler, F. (2020). "Pandemic fear" and COVID-19: Mental health burden and strategies. Revista Brasileira de Psiquiatria, 42, 232-235. https://doi.org/10.1590/1516-44462020-0008

Polizzi, C., Lynn, S. J., Perry, A. (2020). Stress and coping in the time of COVID-19: Pathways to resilience and recovery. Clinical Neuropsychiatry, 17, 59-62. https://doi.org/10.36131/CN20200204

Preacher, K. J., \& Hayes, A. F. (2008). Asymptotic and resampling strategies for assessing and comparing indirect effects in multiple mediator models. Behavior Research Methods, 40, 879-891. https:// doi.org/10.3758/BRM.40.3.879

Qiu, J., Shen, B., Zhao, M., Wang, Z., Xie, B., \& Xu, Y. (2020). A nationwide survey of psychological distress among Chinese people in the COVID-19 epidemic: Implications and policy recommendations. General Psychiatry, 33, e100213. https://doi. org/10.1136/gpsych-2020-100213

Rubin, G. J., Potts, H. W., \& Michie, S. (2010). The impact of communications about swine flu (influenza A H1N1v) on public responses to the outbreak: Results from 36 national telephone surveys in the UK. Health Technology Assessment, 14, 183-266. https://doi.org/10.3310/hta14340-03

Satici, B., Gocet-Tekin, E., Deniz, M. E., \& Satici, S. A. (2020). Adaptation of the Fear of COVID-19 Scale: Its association with psychological distress and life satisfaction in Turkey. International Journal of Mental Health and Addiction. https:// doi.org/10.1007/s11469-020-00294-0

Shigemura, J., Ursano, R. J., Morganstein, J. C., Kurosawa, M., \& Benedek, D. M. (2020). Public responses to the novel 2019 coronavirus (2019-nCoV) in Japan: Mental health consequences and target 
populations. Psychiatry and Clinical Neurosciences, 74, 281-282. https://doi.org/10.1111/pcn. 12988

Sood, S. (2020). Psychological effects of the coronavirus disease-2019 pandemic. Research \& Humanities in Medical Education, 7, 23-26.

Su, T. P., Lien, T. C., Yang, C. Y., Su, Y. L., Wang, J. H., Tsai, S. L., \& Yin, J. C. (2007). Prevalence of psychiatric morbidity and psychological adaptation of the nurses in a structured SARS caring unit during outbreak: a prospective and periodic assessment study in Taiwan. Journal of Psychiatric Research, 41, 119130. https://doi.org/10.1016/j.jpsychires.2005.12.006

Van Bortel, T., Basnayake, A., Wurie, F., Jambai, M., Koroma, A. S., Muana, A. T., Hann, K., Eaton, J., Martin, S., \& Nellums, L. B. (2016). Psychosocial effects of an Ebola outbreak at individual, community and international levels. Bulletin of the World Health Organization, 94, 210-214. https:// doi.org/10.2471/BLT.15.158543

Wang, C., Pan, R., Wan, X., Tan, Y., Xu, L., Ho, C. S., \& Ho, R. C. (2020). Immediate psychological responses and associated factors during the initial stage of the 2019 coronavirus disease (COVID-19) epidemic among the general population in China. International Journal of Environmental Research and Public Health, 17, 1729. https://doi.org/10.3390/ ijerph17051729

Wheaton, M. G., Abramowitz, J. S., Berman, N. C., Fabricant, L. E., \& Olatunji, B. O. (2012). Psychological predictors of anxiety in response to the H1N1 (swine flu) pandemic. Cognitive Therapy and Research, 36, 210-218. https://doi.org/10.1007/ s10608-011-9353-3

World Health Organization (2020). Coronavirus disease (COVID-2019): Situation report-146. Retrieved from https://www.who.int/docs/default-source/ coronaviruse/situation-reports/20200614-covid19-sitrep-146.pdf?sfvrsn=5b89bdad_6 [accessed June 14, 2020]

Wu, P., Fang, Y., Guan, Z., Fan, B., Kong, J., Yao, Z., Liu, X., Fuller, C. J., Susser, E., Lu, J., \& Hoven, C. W. (2009). The psychological impact of the SARS epidemic on hospital employees in China: Exposure, risk perception, and altruistic acceptance of risk. Canadian Journal of Psychiatry. Revue Canadienne de Psychiatrie, 54, 302-311. https:// doi.org/10.1177/070674370905400504

Xiao, H., Zhang, Y., Kong, D., Li, S., \& Yang, N. (2020). Social capital and sleep quality in individuals who self-isolated for 14 days during the coronavirus disease 2019 (COVID-19) outbreak in January 2020 in China. Medical Science Monitor, 26, e923921. https://doi.org/10.12659/MSM.923921

Ye, Q., Wang, B., Mao, J., Fu, J., Shang, S., Shu, Q., \& Zhang, T. (2020). Epidemiological analysis of COVID-19 and practical experience from China. Journal of Medical Virology, 92, 755-769. https:// doi.org/10.1002/jmv.25813
Yip, P. S. F., Cheung, Y. T., Chau, P. H., \& Law, Y. W. (2010). The impact of epidemic outbreak: The case of severe acute respiratory syndrome (SARS) and suicide among older adults in Hong Kong. Crisis, 31, 86-92. https://doi.org/10.1027/0227-5910/a000015

Zhang, X., Wang, Y., Lyu, H., Zhang, Y., Liu, Y., \& Luo, J. (2020). The Influence of COVID-19 on well-being. PsyArXiv. https://doi.org/10.31234/osf.io/znj7h

Zhu, X., Wu, S., Miao, D., \& Li, Y. (2008). Changes in emotion of the Chinese public in regard to the SARS period. Behavior and Personality, 36, 447-454. https://doi.org/10.2224/sbp.2008.36.4.447
COVID-19, stress, pandemic, quality of life 


\section{FEAR OF COVID-19 SCALE (FOC-6)}

(Dymecka et al., 2020)

The following statements relate to your thoughts and feelings during the last month in connection to the coronavirus pandemic (COVID-19). We are interested in your subjective thoughts and feelings about the coronavirus. Please indicate to what extent the presented statements refer to your feelings and thoughts.

Joanna Dymecka, Rafał Gerymski, Anna MachnikCzerwik There are neither right or wrong answers. Please answer all using the following scale:

1 - I strongly disagree

2 - I disagree

3 - I do not have an opinion

4 - I agree

5 - I definitely agree

1. I am afraid of losing my life due to coronavirus infection.

2. I am afraid of serious health complications due to coronavirus infection (e.g. permanent lung damage).

3. I am afraid of long forced hospitalization due to coronavirus infection.

4. I am afraid that I will be isolated from my family and friends due to the pandemic.

5. I am afraid of losing my job and income due to the pandemic.

6. I am afraid that I will lose a person who is close to me / a loved one due to the pandemic.
$\begin{array}{lllll}1 & 2 & 3 & 4 & 5\end{array}$
$\begin{array}{lllll}1 & 2 & 3 & 4 & 5\end{array}$
$\begin{array}{lllll}1 & 2 & 3 & 4 & 5\end{array}$
$\begin{array}{llll}2 & 3 & 4 & 5\end{array}$
$\begin{array}{lllll}1 & 2 & 3 & 4 & 5\end{array}$
$\begin{array}{lllll}1 & 2 & 3 & 4 & 5\end{array}$ 


\section{KWESTIONARIUSZ OCENY LĘKU PRZED COVID-19 \\ FEAR OF COVID-19 SCALE (FOC-6) \\ (Dymecka et al., 2020)}

Poniższe twierdzenia dotyczą Twoich myśli i odczuć przeżywanych w ostatnim miesiącu w związku z pandemią koronawirusa (COVID-19). Interesują nas Twoje subiektywne myśli i uczucia związane z koronawirusem. Proszę wskazać, w jakim stopniu każde ze stwierdzeń odnosi się do Pana/Pani odczuć i myśli. Nie ma tutaj odpowiedzi dobrych lub złych. Proszę odpowiedzieć na wszystkie stwierdzenia za pomocą poniższej skali:

1 - zdecydowanie się nie zgadzam

COVID-19, stress, pandemic, quality of life

2 - raczej się nie zgadzam

3 - nie mam zdania

4 - raczej się zgadzam

5 - zdecydowanie się zgadzam

\begin{tabular}{|c|c|c|c|c|}
\hline 1. Obawiam się utraty życia w związku z zarażeniem koronawirusem. & 1 & 2 & 3 & 4 \\
\hline $\begin{array}{l}\text { 2. Obawiam się poważnych komplikacji zdrowotnych z powodu koronawirusa } \\
\text { (np. trwałe uszkodzenie płuc). }\end{array}$ & 1 & 2 & 3 & 4 \\
\hline $\begin{array}{l}\text { 3. Obawiam się długiej przymusowej hospitalizacji w związku z zarażeniem } \\
\text { koronawirusem. }\end{array}$ & 1 & 2 & 3 & 4 \\
\hline $\begin{array}{l}\text { 4. Obawiam się, że w związku z pandemią koronawirusa będę odizolowany od mojej } \\
\text { rodziny i przyjaciół. }\end{array}$ & 1 & 2 & 3 & 4 \\
\hline 5. Obawiam się utraty dochodu i straty pracy w związku z pandemią koronawirusa. & 1 & 2 & 3 & 4 \\
\hline 6. Obawiam się, że w związku z pandemią koronawirusa utracę bliską mi osobę. & 1 & 2 & 3 & 4 \\
\hline
\end{tabular}

